\title{
RANTAI PEMASARAN IKAN KOI (Cyprinus carpio) DI KABUPATEN BLITAR, JAWA TIMUR
}

\author{
Riesti Triyanti dan Maharani Yulisti \\ Balai Besar Penelitian Sosial Ekonomi Kelautan dan Perikanan \\ JI. KS. Tubun Petamburan VI Jakarta 10260 \\ Telp. (021) 53650162, Fax. (021)53650159 \\ Diterima 21 Feb 2012- Disetujui 24 Mei 2012
}

\begin{abstract}
ABSTRAK
Pemasaran merupakan salah satu subsistem penting dalam sistem minabisnis. Kegiatan pemasaran merupakan kegiatan perpindahan tempat dan kepemilikan barang dan jasa dari sentra pra produksi ke konsumen. Kegiatan pemasaran bertujuan untuk memenuhi permintaan konsumen serta memberikan keuntungan bagi pembudidaya. Penelitian ini bertujuan untuk mengidentifikasi rantai pemasaran ikan koi (Cyprinus carpio) di Kecamatan Nglegok, Kabupaten Blitar. Penelitian dilakukan pada bulan Juni sampai dengan Juli 2011. Hasil penelitian menunjukkan bahwa rantai pemasaran ikan koi dimulai dari tahap pra produksi, produksi, pedagang dan eksportir. Setiap rantai terdapat pelaku usaha kunci dan nilai/keuntungan yang relatif dinamis karena tergantung pada nilai estetika terhadap ikan koi. Untuk memperkuat rantai pemasaran ikan koi diperlukan pembentukan kelembagaan keuangan untuk menertibkan sistem pembayaran terhadap pembelian ikan koi yang seringkali merugikan pembudidaya. Penelitian ini juga menyarankan perlunya menghidupkan kembali koperasi yang telah dibentuk agar pemasaran ikan koi dikoordinir dan harganya standar.
\end{abstract}

Kata kunci: rantai pemasaran, ikan koi, Kabupaten Blitar

Abstract : Koi Fish (Cyprinus carpio) Marketing Chain in Blitar Regency, East Java. By : Riesti Triyanti and Maharani Yulisti.

Marketing is one of the important subsystems in the system of fisheries business. Marketing activities is a displacement and ownership of goods and services from pre-production to the consumer centers. Marketing in fisheries business aims to fulfill consumer demand as well as to provide benefits to fish breeders and aquaculturist. This study is to identify the marketing chain of koi fish (Cyprinus carpio) in Nglegok District, Blitar. This study was conducted from June to July 2011. The research results showed that koi fish marketing chain starting from pre production, production, traders to exporters. Each chain has the key business performer and benefit that relatively dynamic depending on the aesthetic value of the koi fish. To strengthen marketing chain of koi fish this study recommended the establishment of financial institutions to make fair payment system to fish farmers. This study suggest needs to revitalize cooperative for coordinating marketing of koi fish and standardize its price.

Keywords : marketing chains, koi fish, Blitar Regency

\section{PENDAHULUAN}

Ikan hias merupakan salah satu komoditas perikanan yang banyak diminati oleh berbagai lapisan masyarakat di dalam negeri maupun di luar negeri karena komposisi warna yang dimilikinya. Salah satu jenis ikan hias air tawar yang digemari oleh masyarakat adalah ikan koi yang tergolong dalam salah satu strain ikan mas (Cyprinus carpio). Para penggemar ikan koi atau hobbies di Indonesia tidak hanya memelihara ikan koi di kolam, tetapi juga diikutsertakankan dalam kontes koi sehingga dapat menaikkan gengsi bagi pemiliknya.

Kabupaten Blitar merupakan salah satu sentra ikan koi di Indonesia. Budidaya ikan koi di Blitar sudah dimulai sejak tahun 1983 dan bertambah maju serta menjadi lahan usaha baru yang sangat menjanjikan bagi pembudidaya ikan dan para investor. Lebih dari 700 pembudidaya di Kabupaten Blitar membudidayakan ikan koi dengan luas areal 20,75 hektar dan tersebar di beberapa kecamatan (Anonimous, 2010). Sampai saat ini Blitar sudah dikenal oleh pedagang maupun penggemar sebagai sentra budidaya ikan koi dan telah memiliki pasar yang cukup luas, bahkan untuk wilayah Jakarta, Bandung, Bogor, Surabaya, Semarang dan Bali. Meningkatnya jumlah pembudidaya di Kabupaten Blitar dari tahun ke tahun maka suatu saat pembudidaya akan berhadapan dengan masalah penyaluran hasil usaha budidayanya. Penelitian ini bertujuan untuk mengidentifikasi rantai pemasaran ikan koi di Kabupaten Blitar, Jawa Timur.

\section{BUDIDAYA IKAN KOI}

Desa Kemloko, Kecamatan Nglegok mempunyai luas wilayah 327,13 Ha. Secara geografis letak desa ini berada pada koordinat $8^{\circ}-8^{\circ} 9^{\prime} \mathrm{LU}$ dan $112^{\circ}-112^{\circ} 21^{\prime} \mathrm{BT}$, dengan batas wilayah :

- Batas Utara : Desa Penataran

- Batas Selatan : Desa Bangsri

- Batas Timur : Desa Bangsri dan Desa Dayu

- Batas Barat : Desa Nglegok 
Desa ini memiliki jenis tanah yang liat dan berpasir sehingga sangat potensial dalam kegiatan perikanan, terutama budidaya ikan air tawar. Jenis ikan yang di budidayakan di Desa Kemloko antara lain ikan koi, ikan nila, ikan gurami, dan ikan lele. Sebagian besar masyarakat Desa Kemloko membudidayakan ikan koi dengan luas lahan 20,75 Ha. Data mengenai potensi perikanan di Kabupaten Blitar disajikan dalam Tabel 1.

\section{a. Benih Ikan}

Benih ikan untuk budidaya ikan koi di Kecamatan Nglegok diperoleh dengan cara melakukan pemijahan sendiri. Untuk setiap pemijahan menghasilkan $10.000-$ 50.000 ekor benih ikan koi. Pemijahan ini dilakukan dua sampai tiga kali setahun. Benih ikan koi dikembangkan dalam jumlah yang banyak namun dari segi kualitas dapat dikatakan kurang baik, karena beberapa induk sudah terlalu tua untuk berproduksi (afkir).

Tabel 1. Budidaya Ikan Hias di Kabupaten Blitar Tahun 2008 - 2010.

\begin{tabular}{cccccc}
\hline Tahun & $\begin{array}{c}\text { RTP } \\
\text { (unit) }\end{array}$ & $\begin{array}{c}\text { Pembudidaya } \\
\text { (orang) }\end{array}$ & $\begin{array}{c}\text { Total Luas } \\
\text { Kolam (Ha) }\end{array}$ & $\begin{array}{c}\text { Produksi/Thn } \\
\text { (Ekor) }\end{array}$ & $\begin{array}{c}\text { Nilai Produksi } \\
\text { (Rp 1.000) }\end{array}$ \\
\hline 2008 & 364 & 1.456 & 51,2 & 246.427 .000 & 664.820 .000 \\
2009 & 364 & 1.456 & 51,2 & 141.492 .500 & 707.462 .500 \\
2010 & 370 & 1.456 & 51,2 & 142.300 .000 & 711.500 .000 \\
\hline
\end{tabular}

Sumber : Statistik Perikanan Kabupaten Blitar (2008-2010)

Jenis ikan yang terdapat di Kecamatan Nglegok terdiri dari ikan darat, ikan air tawar dan ikan hias dengan total produksi mencapai 18.309 .120 ekor/tahun (Tabel 2). Ikan darat meliputi ikan yang dibudidayakan dengan sistem minapadi dan di perairan umum. Ikan air tawar dibudidayakan di kolam, sawah, waduk, dan jaring apung. Ikan hias merupakan ikan air tawar yang tidak dikonsumsi.

\section{b. Pakan Ikan}

Pakan ikan yang digunakan pembudidaya adalah Pakan Koi (PK-2), pakan breeder pro dan pakan cacing sutra. Pakan ikan didapatkan dari daerah Surabaya dan Sidoarjo, karena di Kecamatan Nglegok masih belum terdapat industri pakan ikan. Kebutuhan pakan ikan di pasok oleh CV Prima Surabaya

Tabel 2. Budidaya Ikan Hias Koi di Kecamatan Nglegok Tahun 2008.

\begin{tabular}{|c|c|c|c|c|}
\hline \multirow{2}{*}{ Desa } & \multicolumn{2}{|c|}{ Luas Kolam (m²) } & \multirow{2}{*}{$\begin{array}{l}\text { Total Luas Kolam } \\
\qquad\left(\mathrm{m}^{2}\right)\end{array}$} & \multirow{2}{*}{$\begin{array}{l}\text { Prod/Thn } \\
\text { (Ekor) }\end{array}$} \\
\hline & Beton & Tanah & & \\
\hline Desa Ngoran & 90 & 9.700 & 9.790 & 469.920 \\
\hline Desa Dayu & - & 5.960 & 5.960 & 286.080 \\
\hline Desa Modangan & 180 & 5.320 & 5.500 & 264.000 \\
\hline Desa Jiwut & 191 & 13.580 & 13.771 & 661.008 \\
\hline Kelurahan Nglegok & 3.150 & 70.970 & 74.120 & 3.557 .760 \\
\hline Desa Bangsri & 1.325 & 3.500 & 4.825 & 231.600 \\
\hline Desa Krenceng & 3.531 & 33.720 & 37.251 & 1.788 .048 \\
\hline Desa Kemloko & 5.733 & 224.490 & 230.223 & 11.050 .704 \\
\hline Jumlah & 14.110 & 367.240 & 381.440 & 18.309 .120 \\
\hline
\end{tabular}

Sumber : Kecamatan Nglegok dalam Angka (2008)

Input produksi perikanan di Kecamatan Nglegok dapat dipahami sebagai keseluruhan kegiatan di sektor perikanan yang menyediakan barangbarang modal untuk keperluan produksi perikanan, seperti pembenihan, agro-kimia, pakan ikan, wadah budidaya, maupun sumberdaya energi seperti air, sebagai berikut : dan kios-kios pakan yang ada di Kecamatan Nglegok dengan harga berkisar antara Rp 7.000 - 15.000 per kg atau sekitar Rp 90.000,- per sak. Jumlah kebutuhan pakan ikan untuk ikan koi adalah $1 \mathrm{~kg}$ untuk ikan koi umur 0-6 bulan. 


\section{c. Pupuk}

Di Kecamatan Nglegok, unit usaha yang menghasilkan pupuk belum tersedia. Kebutuhan pupuk yang digunakan oleh pembudidaya terutama pupuk kandang, pupuk organik, pupuk anorganik (Triple Super Phosphate/TSP, urea, amonium sulfat/ZA) yang dipasok oleh PT. Petrokimia Gresik untuk kemudian di distribusikan oleh distributor swasta ke seluruh wilayah kecamatan dengan harga mencapai sekitar Rp 150.000,per rit.

\section{d. Obat-obatan}

Jenis obat-obatan yang biasa dipakai pembudidaya di Kecamatan Nglegok adalah garam, antibiotik, vitamin, Malachite Green Oxalate/ MGO, antibiotik untuk infeksi ikan hias (Elbayou), yang diperoleh di apotik-apotik kecamatan. Jadwal pemberian obat-obatan adalah saat menjelang pancaroba yaitu sekitar bulan Maret dan pertengahan bulan April selanjutnya dibutuhkan masa penyembuhan selama 1-3 minggu.

\section{e. Lahan}

Luas lahan untuk pengembangan budidaya ikan koi di Kecamatan Nglegok adalah $381.440 \mathrm{~m}^{2}$. Lahan budidaya ikan yang digunakan berupa sawah dan kolam beton dengan bentuk dan ukuran berdasarkan petak sawah sekitar $1.000 \mathrm{~m}^{2}$ per petak dan kolam beton dengan ukuran $4 \mathrm{~m} \times 7 \mathrm{~m}$ dengan status kepemilikan sewa atau milik sendiri.

\section{d. Modal}

Permodalan untuk usaha budidaya berasal dari swadaya pembudidaya dan pinjaman kredit dari lembaga keuangan yaitu BRI dan BPR. Bantuan pemerintah baru diadakan tahun ini yaitu Program Usaha Mina Pedesaan (PUMP).
Tahapan pra produksi usaha budidaya ikan koi meliputi ketersediaan dan pasokan benih dan pakan. Kebutuhan dan potensi benih, pakan serta produksi ikan koi di Kabupaten Blitar mencapai 1.317, 68 ton pada tahun 2008 (Tabel 3).

Usaha budidaya ikan koi di Kabupaten Blitar pada tahun 2008 mengalami perkembangan yang signifikan dibandingkan tahun-tahun sebelumnya. Luas areal potensial yang dapat dimanfaatkan untuk kegiatan budidaya ikan koi adalah seluas $60.785 \mathrm{Ha}$ dengan luas areal yang baru termanfaatkan sebesar $38.144 \mathrm{Ha}$ atau $39 \%$ dari luas areal potensial. Jumlah benih yang dibutuhkan dalam usaha budidaya ikan koi sebesar 58.240.000 ekor sedangkan ketersediaannya juga sama dengan benih yang dibutuhkan. Hal ini dikarenakan pembudidaya tidak mendatangkan benih dari luar dan benih ikan koi yang tersedia mampu memenuhi kebutuhan yang pembudidaya yang ada. FCR pakan rata-rata adalah sekitar 0,00007 (Tabel 3), nilai FCR yang sangat kecil menunjukkan bahwa kebutuhan pakan untuk usaha budidaya tidak banyak karena tergantung dari selera pembudidaya untuk menambah warna dalam corak ikan.

\section{RANTAI PEMASARAN IKAN KOI}

Menurut Mubyarto (1989) dalam Melani (2002), pemasaran atau distribusi, yaitu semacam kegiatan ekonomi yang berfungsi membawa atau menyampaikan barang dari produsen ke konsumen. Sedangkan menurut Hanafiah dan Saefuddin (1983) dalam Melani (2002), salah satu ciri pemasaran hasil perikanan adalah saluran pemasaran hasil perikanan yang umumnya terdiri dari produsen, pedagang perantara dan konsumen. Pemetaan pelaku usaha budidaya ikan koi di Kabupaten Blitar dikelompokkan ke dalam empat tahap rantai pemasaran (Gambar 1) yaitu tahap (1) pra produksi, (2) produksi, (3) distribusi/ pemasaran dan (4) konsumen.

Tabel 3. Potensi dan Kebutuhan Benih, Pakan dan Produksi Ikan Koi di Kabupaten Blitar Tahun 2008.

\begin{tabular}{clc}
\hline No. & \multicolumn{1}{c}{ Uraian } & \multicolumn{1}{c}{$\mathbf{2 0 0 8}$} \\
\hline 1. & Luas Areal (Potensi) (Ha) & 60.785 \\
2. & Luas Areal (Existing) (Ha) & 38.144 \\
3. & Kebutuhan Benih ikan koi (ekor) & 58.240 .000 \\
4. & Ketersediaan Benih ikan koi (ekor) & 58.240 .000 \\
5. & Kebutuhan Pakan ikan (ton) & $1.317,68$ \\
6. & Produksi Ikan koi (ekor) & 18.309 .120 \\
\hline & FCR & 0,000071969 \\
\hline
\end{tabular}

Sumber : $\quad$ Data Statistik Perikanan, Dinas Kelautan dan Perikanan Kabupaten Blitar 2008 (No 1, 2, dan 6) dan data primer (2011) diolah (No 3, 4, dan 5)

Keterangan :

- Kebutuhan benih yang dimaksud adalah kebutuhan benih untuk sekali pemijahan.

- Ketersediaan benih yang dimaksud adalah ketersediaan benih dari pembudidaya di Kabupaten Blitar dan tidak ada benih dari luar kab/kawasan.

Kebutuhan pakan yang dimaksud adalah dari larva, benih, sampai dengan 2 bulan pemeliharaan. 


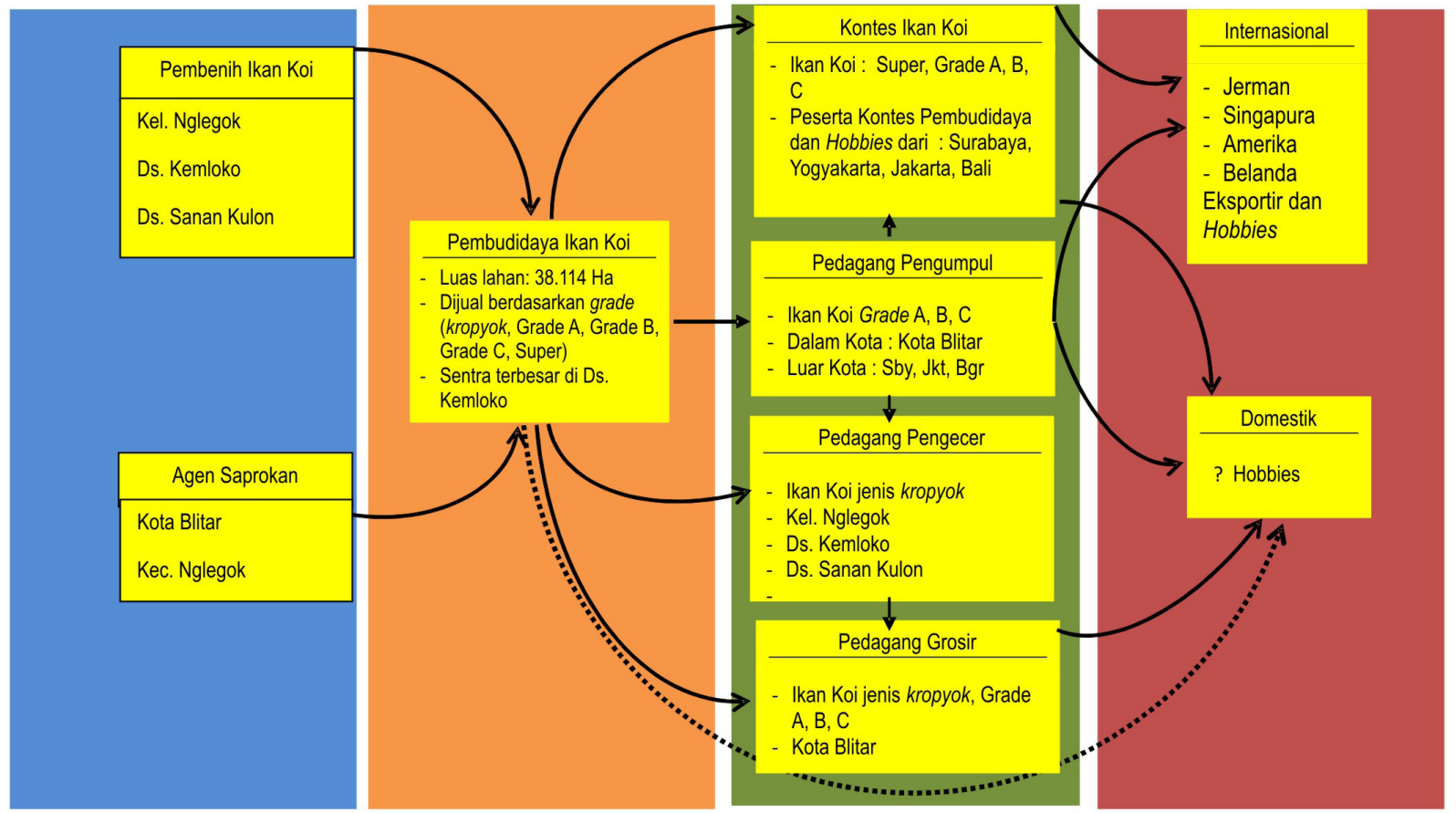

Sumber: Data Primer (2011)

Gambar 1. Rantai Pemasaran Ikan Koi di Kabupaten Blitar

\section{Tahap Pra Produksi}

\section{Pembenih}

Produksi benih ikan koi yang dihasilkan oleh pembudidaya sudah memenuhi seluruh kebutuhan benih pembudidaya di Kabupaten Blitar. Benih yang dihasilkan oleh pembudidaya tidak dijual ke pembudidaya yang lain tetapi digunakan sendiri oleh pembudidaya tersebut. Kualitas benih ikan koi tergantung pada kualitas induk. Penggunaan induk dengan kualitas yang baik akan sangat menentukan hasil yang didapat. Kesalahan dalam memilih induk dapat menghasilkan keturunan yang jelek dan jumlahnya sedikit. Untuk itu induk yang akan digunakan dalam kegiatan pemijahan harus memenuhi beberapa kriteria. Kriteria yang diterapkan untuk induk ikan koi adalah (Susanto dan Rochdianto, 2007) :

1. Induk ikan dalam keadaan sehat dan tidak cacat atau luka.

2. Memiliki tubuh yang normal, yaitu melengkung sempurna dan tidak ada bagian yang datar dipunggung.

3. Induk ikan berumur 2 tahun atau lebih dan telah matang gonad.

4. Induk ikan memiliki sisik yang besar dan tersusun teratur serta warna yang tegas dan kontras.

5. Induk ikan memiliki ukuran kepala yang kecil dan tutup insang yang tidak terlalu tebal atau tipis.
6. Induk ikan berasal dari keturunan yang berbeda atau tidak berkerabat dekat.

\section{Penjual Saprokan (Pakan Ikan)}

Jenis pakan yang digunakan oleh pembudidaya ikan koi terdiri dari pakan alami dan pakan pabrik. Pakan alami terdiri dari kuning telur yang dicampur dengan tepung susu untuk larva sampai dengan benih (5-8 hari) selanjutnya pada umur 8-20 hari diberikan pakan cacing rambut. Kebutuhan pakan alami dalam satu siklus pemeliharaan sebanyak $1 \mathrm{~kg}$ dengan harga Rp $16.000 / \mathrm{kg}$. Pakan pabrikan umumnya diperoleh dari agen yang ada di Kabupaten Blitar. Pakan yang digunakan oleh pembudidaya diproduksi di Sidoarjo, Mojokerto dan Banten. Kandungan protein pakan pabrik yang digunakan pembudidaya adalah sebesar $21 \%$. Harga jual pakan ikan ke pembudidaya adalah Rp 7.160/ kg (Rp. 215.000/30 kg) dengan sistem pembayaran pakan umumnya dilakukan secara tunai.

\section{Tahap Produksi}

\section{Pembudidaya}

Untuk mendapatkan ikan dengan kualitas bagus, pembudidaya ikan koi di Kabupaten Blitar selalu melakukan proses seleksi. Ikan diseleksi mulai dari umur 1 sampai 6 bulan dengan persentase seperti pada Tabel 4. 
Tabel 4. Persentase Penyeleksian Ikan Koi.

\begin{tabular}{|c|c|c|c|c|c|}
\hline Seleksi & Umur & \% Seleksi & Jumlah Ikan (Ekor) & Hasil ( Ekor ) & Keterangan \\
\hline 1 & $\begin{array}{c}1-2 \\
\text { Bulan }\end{array}$ & $10 \%$ & 100.000 & 10.000 & Kualitas jelek \\
\hline II & $\begin{array}{l}2-3 \\
\text { Bulan }\end{array}$ & $50 \%$ & 10.000 & 5.000 & Kropyokan \\
\hline III & $\begin{array}{l}3-4 \\
\text { Bulan }\end{array}$ & $50 \%$ & 5.000 & 2.500 & $\begin{array}{l}\text { Kualitas C- } \\
\text { Kropyokan }\end{array}$ \\
\hline IV & $\begin{array}{l}4-6 \\
\text { Bulan }\end{array}$ & $20 \%$ & 2.500 & 500 & Kualitas A, B/ C \\
\hline
\end{tabular}

Sumber : Data primer diolah (2011)

Kriteria seleksi didasarkan pada ketajaman warna, pola yang bagus, serta bentuk tubuh yang sempurna dan sehat. Untuk seleksi pertama biasanya dilakukan saat ikan berumur $1-2$ bulan, tujuannya adalah untuk mengurangi jumlah populasi dan disesuaikan dengan luas kolam yang dimiliki. Seleksi juga bertujuan untuk mengefisienkan pemberian pakan. Seleksi ini biasanya hanya menyisakan \pm 10 $\%$ dari populasi benih, benih yang diseleksi masuk kualitas paling jelek yaitu yang tidak berwarna atau polos serta kondisi fisiknya jelek. Seleksi kedua dilakukan saat ikan berumur $2-3$ bulan yang juga mempunyai tujuan yang sama dengan hanya menyisakan $\pm 50 \%$ dari hasil seleksi pertama, dan yang tidak lolos disebut koi kropyokan.

Setelah benih berumur $3-4$ bulan dilakukan seleksi ketiga, biasanya seleksi lebih ketat dan diambil $\pm 50 \%$ dari hasil seleksi kedua. Ikan koi yang tidak lolos seleksi ketiga umumnya masuk kualitas C - kropyokan. Selanjutnya dilakukan seleksi yang keempat pada saat ikan koi berumur $4-6$ bulan sebanyak $\pm 20 \%$ dari hasil seleksi ketiga, dan dihasilkan ikan koi kualitas A, B dan $C$ yang harganya cukup mahal di pasaran. Koi hasil seleksi keempat inilah yang selanjutnya dipelihara lagi atau dipanen sebagai penghasilan utama usaha budidaya ikan koi.

Isu kunci yang ada pada pelaku usaha di tingkat pembudidaya ini adalah sistem pembayaran menggunakan sistem tempo. Dalam hal ini pedagang pengumpul seringkali mangkir untuk membayar utangnya kepada pembudidaya, bahkan dalam sekali pengiriman, jika ada ikan koi yang mati akan dipotong dari total pembelian. Jalan keluar yang diharapkan pembudidaya adalah pembentukan kelembagaan pemasaran (manager) yang dapat mengontrol standar harga dan mengelola keuangan pembudidaya agar tidak mengalami kerugian karena seringkali dibodohi oleh pembeli ikan. Selain itu, permasalahan juga terjadi pada indukan yang sudah afkir dan menurun kualitasnya, sehingga diperlukan bantuan dari pemerintah dengan pengadaan indukan yang bersertifikat. Isu kunci yang lain adalah pada teknis budidaya yaitu seringnya terjadi serangan Koi Herpes Virus/KHV saat perubahan musim (pancaroba) serta pola pikir (mindset) pembudidaya yang harus di ubah dari kuantitas menjadi kualitas.

\section{Tenaga Kerja}

Tenaga kerja yang ada pada kegiatan usaha budidaya ikan adalah tenaga kerja yang bertugas melakukan persiapan kolam yakni membajak tanah dan memupuk. Sistem upah yang digunakan adalah harian yang tergantung pada luas lahan (ru). Kegiatan persiapan kolam umumnya dilakukan oleh tenaga kerja dengan upah harian sekitar Rp 100.000,- per 100 ru ( $1 \mathrm{ru}=14 \mathrm{~m}$ ). Dalam usaha budidaya ikan koi ini tidak ada tenaga kerja pemeliharaan dan pemanenan, karena seleksi dilakukan sendiri oleh pembudidaya.

\section{Tahap Distribusi/Pemasaran}

Ikan koi merupakan ikan hias yang unik. Penjualan ikan koi pun melalui kontes eksklusif yang didasarkan pada nilai estetika, sehingga saat ini ikan koi belum diminati oleh konsumen namun diminati oleh peminat (hobbies). Ikan koi bahkan termasuk dalam urutan pertama didunia yang diminati karena nilai estetikanya (Agus Koi, 2011). Pemasaran pada club-club pecinta ikan koi mengakibatkan harga tidak standar, harga mencapai ratusan ribu dan jutaan rupiah.

Saluran tata niaga bisnis perikanan/rantai pemasaran di Desa Kemloko bermula dari pemilik/ pembudidaya sebagai produsen. Ada tiga macam cara distribusi ikan koi yang ada di lokasi penelitian, yaitu :

\section{- Distribusi Secara Langsung}

Produsen ikan memasarkan ikan langsung ke konsumen, tanpa melalui perantara. Biasanya dilakukan oleh pembudidaya skala kecil.

\section{- Distribusi Semi Langsung}

Produsen menyalurkan hasil produksinya ke tangan pedagang pengecer, kemudian dari pedagang pengecer disalurkan ke konsumen, 


\section{- Distribusi Tidak Langsung}

Biasanya dipengaruhi oleh jarak produsen ke konsumen. Saluran pemasarannya adalah produsen lalu ke pedagang pengumpul diteruskan ke pedagang besar, pedagang pengecer dan akhirnya ke konsumen.

\section{Pedagang Pengumpul dan Pedagang Grosir}

Pedagang pengumpul di Kabupaten Blitar membeli ikan koi dari pembudidaya yang berlokasi di Desa Kemloko dan Nglegok untuk kemudian ditampung untuk disalurkan ke pedagang pengumpul luar kota, eksportir, maupun konsumen dalam negeri (Denpasar, Surabaya, Semarang, Jakarta, Bandung, dan Bogor). Standar harga seringkali tidak dijadikan acuan karena harga tergantung kualitas ikan koi dan kesepakatan penjual dan pembeli. Nilai pembelian mencapai ratusan ribu sampai jutaan rupiah. Banyaknya ikan koi yang diminta juga berfluktuatif, karena tergantung permintaan dari luar kota maupun ketersediaan ikan koi yang ada di Kabupaten Blitar.

\section{Pedagang Pengecer}

Pedagang pengecer umumnya menjual ikan koi dengan ukuran kecil $(6-20 \mathrm{~cm})$ dan tergolong pada jenis ikan kropyokan. Harga ikan bervariasi mulai dari Rp 1.000,- sampai dengan Rp 25.000,-. Konsumen yang membeli ikan tersebut adalah anak-anak dan konsumen dalam kota yang memelihara ikan koi di kolam-kolam rumah. Pedagang pengecer juga memasarkan ikan koi ke pedagang pengecer di Tulungagung.

\section{Kontes Ikan Koi (Blitar Koi Show)}

Salah satu usaha pemasaran yang dilakukan adalah dengan promosi yaitu melalui ajang kontes, pameran, maupun kegiatan-kegiatan lain yang terkait dengan perikanan koi. Kegiatan tersebut bertujuan untuk menciptakan citra (image) bahwa ikan koi Blitar, mempunyai kualitas yang baik. Peran Pemerintah Kabupaten melalui Dinas Kelautan dan Perikanan sangat besar dalam mendukung pemasaran ikan koi, yaitu dengan membangun Pusat Informasi Pemasaran Ikan Koi guna mempermudah penggemar (hobbies) dan pedagang ikan koi untuk mendapatkan informasi tentang budidaya koi maupun profil para pembudidaya koi di Blitar. Kegiatan tersebut telah banyak mendapat perhatian hobbies dan pedagang lokal di sekitar Blitar, bahkan Surabaya, Semarang, Bandung, Jakarta maupun Bali datang langsung ke sentra budidaya tersebut. Pemerintah Kabupaten Blitar juga mendirikan UPT Pusat Informasi Agribisnis Ikan Hias, dimana dalam kompleks UPT tersebut juga terdapat kios-kios yang menjual ikan koi dan juga sarana dan peralatan budidaya ikan koi.

Saat ini, pembudidaya ikan tidak lagi kesulitan dalam memasarkan produk mereka. Bila ikan koi telah siap panen mereka tinggal menghubungi hobbies atau pedagang yang menjadi jaringan dan mereka akan langsung mendatangi lokasi budidaya. Tidak jarang pula pedagang lokal yang mengantar ikan koi tersebut ke daerah-daerah pemasaran. Untuk kelancaran usaha dijalin hubungan dengan Dinas Koperasi dan Usaha Kecil Menengah II, dan sejak 9 September 2003 telah terbentuk koperasi kelompok bernama "Koperasi Serba Usaha Koi Mandiri" dengan Akte Pendirian Koperasi nomor : 33/14/ $\mathrm{BH} / 409.104 / \mathrm{IX} / 2003$ dimana seluruh pembudidaya telah menjadi anggota koperasi.

Peran koperasi dalam mendukung usaha kelompok sangat penting, karena koperasi kelompok tersebut dapat menyediakan simpanan modal usaha dan Sarana Produksi Ikan (Saprokan) bagi anggota yang membutuhkan. Koperasi juga membantu anggota yang kesulitan dalam pemasaran ikan koi serta membuat standar harga ikan koi untuk melindungi anggota maupun pembeli. Meskipun demikian harga tersebut sangat berfluktuasi karena masih tergantung dari kualitas ikan koi maupun kesepakatan antara penjual dan pembeli. Harga standar ikan Koi dapat dilihat pada Tabel 5. Sejak tahun 2010 peran koperasi tersebut sudah tidak ada lagi sehingga pembudidaya kembali mengalami kesulitan dalam hal permodalan dan pemasaran.

\section{Eskportir}

Eksportir ikan koi biasanya melakukan pemasaran ke Jerman, Afrika, Inggris, Singapura, dan Amerika. Para eksportir menghadapi kondisi bahwa permintaan

Tabel 5. Standar Harga Ikan Koi di Kabupaten Blitar Tahun 2010.

\begin{tabular}{lr} 
UKURAN PANJANG $(\mathrm{cm})$ & \multicolumn{1}{c}{ HARGA (Rp) } \\
\hline Ukuran $3-6 \mathrm{~cm}$ & $30-1.000$ \\
Ukuran $6-20 \mathrm{~cm}$ & $1.000-5.000$ \\
Ukuran $20-35 \mathrm{~cm}$ & $5.000-30.000$ \\
Ukuran $35-45 \mathrm{~cm}$ & $30.000-500.000$ \\
Super & $1.000 .000-7.500 .000$ \\
\hline
\end{tabular}

Sumber : Data Kelompok pembudidaya Koi "Sumber Harapan” (2010) 
seringkali tinggi namun ketersediaan ikan koi yang berkualitas hanya sedikit. Salah satu eksportir di Kabupaten Blitar telah terkenal di luar negeri dan pernah menjadi juri kontes ikan koi di Asia. Isu kunci yang ada pada pelaku usaha ini adalah izin bandara (karantina ikan) yang biayanya semakin tinggi dan membutuhkan persyaratan yang rumit.

\section{Tahap Konsumen}

\section{Hobbies dalam dan luar negeri}

Penggemar ikan koi umumnya memelihara ikan koi untuk kepentingan estetika maupun kepercayaan agamanya. Sebagian besar peminat ikan koi adalah warga keturunan Tionghoa/Cina yang percaya bahwa ikan koi adalah sumber rezeki. Bagi peminat yang sangat fanatik merelakan membeli ikan koi dengan harga jutaan. Untuk peminat ikan koi, jarang ikan koi yang dibeli digunakan untuk keperluan budidaya.

\section{KESIMPULAN DAN SARAN}

\section{Kesimpulan}

Berdasarkan hasil penelitian, dapat disimpulkan tiga hal, sebagai berikut :

1. Saluran pemasaran ikan koi di Kabupaten Blitar terdiri dari 3 (tiga) saluran pemasaran. Di tiga saluran pemasaran tersebut belum ada lembaga pemasaran khusus yang berfungsi untuk menstabilkan harga.

2. Pembudidaya umumnya menjual ikan koi langsung ke pedagang dan penggemar luar daerah sehingga menimbulkan permasalahan dalam sistem pembayaran yang umumnya merugikan pembudidaya. Sistem pembayaran yang umumnya berlaku adalah secara tunai atau dibayar setengahnya kemudian dilunasi dalam pembelian berikutnya.

3. Harga ikan koi tidak standar karena tergantung pada nilai estetika ikan koi dan kesepakatan antara penjual dan pembeli. Harga ikan koi bisa mencapai ratusan ribu sampai dengan jutaan rupiah

\section{Saran}

Harga yang standar tidak bisa diberikan pada ikan koi karena tergantung pada nilai estetika terhadap ikan koi sehingga sulit diberikan harga yang standar, namun perlu dilakukan pembentukan kelembagaan keuangan untuk menertibkan sistem pembayaran terhadap pembelian ikan koi yang seringkali merugikan pembudidaya, selain itu perlu menghidupkan kembali koperasi yang telah dibentuk agar pemasaran ikan koi dikoordinir.

\section{DAFTAR PUSTAKA}

Anonimous. 2008. Kecamatan Nglegok dalam Angka. Badan Pusat Statistik Kabupaten Blitar. Blitar. 2010. Statistik Perikanan Kabupaten Blitar. Badan Pusat Statistik Kabupaten Blitar. Blitar. . 2011. Data Kelompok Pembudidaya Koi "Sumber Harapan" Kabupaten Blitar. Blitar.

Melani, Y. 2002. Analisis Saluran Pemasaran Ikan Koi di Kecamatan Cisaat, Kabupaten Sukabumi, Jawa Barat. Skripsi Fakultas Fakultas Perikanan dan Ilmu Kelautan IPB. Bogor.

Susanto, H., dan Rochdianto, A. 2007. Kiat Budidaya Ikan Mas di Lahan Kritis. Penebar Swadaya. Jakarta. 